\title{
Impact of Training Programs on Human Development: A study on Private Commercial Banks of Bangladesh
}

\author{
Md. Rafiul Islam \\ Lecturer of Accounting; Pundra University of Science \&Technology, Gokul, Bogra-5800, Bangladesh. \\ *Corresponding Author: Md. Rafiul Islam*, Lecturer of Accounting; Pundra University of Science \\ \&Technology, Gokul, Bogra-5800,Bangladesh.Email: rafiulais@gmail.com
}

\begin{abstract}
The study focuses on impact of training program on the human development (basically skill development of Employee) in Private Commercial Banks in Bangladesh. Different types of training programs have been considered to find out the authentic result. To serves the objectives of the study different variables like, Frequency of training, methods of training, quality of training etc been considered. In this study the researcher studies the existing practices of the various aspects of training program and its' effectiveness in Private Commercial Banks in Bangladesh. A structured questionnaire survey was conducted among Private Commercial Banks in Bangladesh to identify the methods and techniques used to train the employee private banking sector in Bangladesh. The findings (Hypothesis test) show that there is positive impact of training program on human development in Bangladeshi Commercial Banking sector.
\end{abstract}

Keywords: Training, Hypothesis, Training quality, Commercial bank, Development program etc.

\section{INTRODUCTION}

Training and development is a function of human resource management concerned with organizational activity aimed at developing the performance of individuals and groups in organizational settings. It has been known by several names, including "human resource development", and "learning and development". Training and development is a subsystem of an organization. It ensures that randomness is reduced and learning or behavioral change takes place in structured format.

Management development program is any attempt to improve managerial performance by improving the knowledge, changing attitudes, or increasing skills. The management development process consists of (1) assessing the company's strategic needs, (2) appraising manager's current performance and then (3) developing the managers. Training is a part of the company's development programs.

Banking system occupies an important place in a nation's economy because of its intermediary role; it ensured allocation and keeps up the momentum of economic activities. A banking institution is indispensable in a modern sociality vice its various socio-economical perspectives. It plays a crucial role in the economic development of country and forms the care at the money market in any cost. The glorious performance of banking sector leads to higher economic growth of an economy. This function can be done by the efficient manpower.

The study is conducted mainly to know about different training programs in private commercial banks and find out the effectiveness of training in private commercial banks in Bangladesh. The present day economy is very much dependent upon the various functions of banking practices; it is unthinkable for the country's economy for its growth, sustenance and development without the role of banks. The role of banks is essentially carried out by the people and therefore it is essential to have a well-trained and motivated staff to manage the banking operations. Success of the banking operations depends upon the people, the employee and the effectiveness of the employee is very much depending on the training input given to the employees. The effectiveness of training is not static, it has to be periodically reviewed, updated and upgraded tuning with the demanding situation of the economy, government policy, advancements in Information Technology and expectations of customers. 


\section{OBJECTIVES OF THE STUDY}

The main objective of the study is to find the impact of training programs on human development.

The specific objectives of the study are following-

1. To know the nature of training programs available to the commercial banks.

2. To unearth the circumstances when management feels the necessity of training of employees.

3. To find the association between effectiveness of training and growth and result of banks.

\section{Literature OVERVIEW}

Rebeka Sultana Liza, Md.Abul Mohaimen, Tahmina Ferdous, investigate the methods, process, and analysis of the internal training needs arranged and maintained by the Human resources managers of Private and Public Banks in Bangladesh. The study reveals that the trained employees help the firms' drive and competitiveness but it is difficult to understand the need assessment before training.

Hameed and Waheed (2008) analyzes the theoretical framework \& models related to employee development and its affect on employee performance and develops a proposed model which explains the relationship between employee development variables (employee learning, skill growth, self directed, employee attitude) and employee performance variable.

Donald L. Kirkpatrick (1997), Evaluation, Training and Development Handbook approached its, evaluation process in a more logical way. The author emphasized that while evaluating training, instead of just studying the reactions of the trainees, the study could be carried out in four different levels viz., i.e., reaction, learning, behavior and results. The author's guidelines and discussions on each level of evaluation of training are worth mentioning.

Mehedi Hasan, Md. Hefzur Rahman, Md. Arifur Rahman have been alleged that Private Commercial Banks (PCBs) in Bangladesh are not out of the frame of the sustainability of a business is highly dependent on the process of how the workforce is informed and trained with state-of-the-art knowledge, skills and how their attitudes are being groomed in order to maintain sensitivity towards the environmental change. The role of PCBs is critically appraised in the economic development and trade proliferation. The aim of this paper is to unearth how the existing training and management development program is perceived by employees.

Role of Training in Developing Human Resources is another work of relevance. In this, the authors concluded that an organization should have well-defined training policy as well as training manual and training should be made an ongoing process. Regarding the executive development programs the authors have concluded that, these programs have been found to be useful in improving the productivity, efficiency and effectiveness of managers. Shishupal Singh Badhu and Karunesh Saxena (1999).

The current research study differs from the studies reviewed in the past, in this study the researcher endeavored to find out the different training program and evaluated the effectiveness of training in private commercial banks and how training increase the job performance is clearly examined.

\section{Methodology OF THE STUdy}

Collection of accurate information is highly dependent on the survey techniques used in case of primary sources of data. In this study, both quantitative and qualitative techniques like, Structured questionnaire (open ended and closed), in-depth interview, case study method, Focus Group discussion (FGD) have been used. Variables have been considered to serve the objectives of the study. Data have also been collected from secondary sources such as different journals, Magazines, websites and Bank record. Total sample size been considered as 50 in number (Employee/ respondents) from 20 studied Private Commercial Bank in Bangladesh. Descriptive statistics such as Table, Graph, Percentage presentation and analytical statistical tools such as Z-test, Hypothesis test have been used to reach the result.

\section{ANALYSIS OF DATA}

The private commercial banks in Bangladesh are very much training oriented. Most of banks organize their training program with the help of their training institute (Such as Mercantile Bank Training 
Institute, National Bank Training Institute, Exim Bank Training Institute etc). The trainers of these training programs are Bangladesh Bank, Bangladesh Institution of Bank Management (BIBM), Institute of Business Administration (IBA), Dhaka University, Renowned academician from different educational institutions etc.

\subsection{There are Various Subject Matters of Training Programs of the Most Private Commercial Banks. The Private Commercial Banks Conduct Training on the Following Grounds}

a) General Banking

b) Credit related training

c) Anti-money Laundering training

d) Online based banking training

e) New software orientation training

f) Foreign exchange training

g) Legal \& Documentation training

h) Training about the new Rules and Policy of Bangladesh Bank

i) Training on the culture and code of the banks

j) Clearing related training

\subsection{The Methods of Training Prevailing in the Private Commercial Banks are}

a) Lecture: A lecture is an oral presentation intended to present information or teach people about a particular subject.

b) Demonstration: Demonstration involves showing by reason or proof, explaining or making clear by use of examples or experiments. Put more simply, demonstration means to clearly show. In teaching through demonstration, learners are set up to potentially conceptualize class material more effectively as shown in a study which specifically focuses on chemistry demonstrations presented by teachers.

c) Discussion: Discussion is the act of instant conversation among the participants.

d) Presentation: Presentation is the method of making understand to the participants.

e) Seminar: A seminar is, generally, a form of academic instruction, either at an academic institution or offered by a commercial or professional organization. It has the function of bringing together small groups for recurring meetings, focusing each time on some particular subject, in which everyone present is requested to actively participate.

All of the surveyed banks use all of the methods. The methods of training vary with the nature of the training.

\subsection{The Status of Different Issues Related to Training are}

\begin{tabular}{|c|l|l|l|l|l|l|l|}
\hline S.I & \multicolumn{1}{|c|}{ Subject } & \multicolumn{2}{c|}{ Yes } & \multicolumn{2}{c|}{ No } & \multicolumn{2}{c|}{ Total } \\
\hline \multirow{2}{*}{1} & $\begin{array}{l}\text { Training since joining the } \\
\text { organization (Graph- } 1 \text { ) }\end{array}$ & No. of person & $(\%)$ & No. of person & $(\%)$ & No. of person & $(\%)$ \\
\cline { 3 - 8 } & 45 & $90 \%$ & 5 & $10 \%$ & 50 & $100 \%$ \\
\hline
\end{tabular}

\begin{tabular}{|c|c|c|c|c|c|c|c|c|c|c|c|c|c|}
\hline $\begin{array}{l}\text { S. } \\
\text { I }\end{array}$ & Subject & $\begin{array}{l}\text { On } \\
\text { join } \\
\text { trai }\end{array}$ & & $\begin{array}{l}\text { Super } \\
\text { Recom }\end{array}$ & dation & Comp & sory & $\begin{array}{l}\text { Emp } \\
\text { Req }\end{array}$ & $\begin{array}{l}\text { pyee } \\
\text { st }\end{array}$ & $\begin{array}{l}\text { Bas } \\
\text { per }\end{array}$ & $\begin{array}{lr}\text { of } \\
\text { ormance }\end{array}$ & $\begin{array}{l}\text { Dor } \\
\text { kno }\end{array}$ & \\
\hline \multirow[t]{2}{*}{2} & \multirow[t]{2}{*}{$\begin{array}{l}\text { Method } \\
\mathrm{s} \text { of } \\
\text { selectio } \\
\mathrm{n} \quad \text { for } \\
\text { training } \\
\text { (Graph- } \\
\text { 2) }\end{array}$} & $\begin{array}{l}\text { No. } \\
\text { of } \\
\text { per } \\
\text { son }\end{array}$ & $(\%)$ & $\begin{array}{l}\text { No. of } \\
\text { person }\end{array}$ & $(\%)$ & $\begin{array}{l}\text { No. } \\
\text { of } \\
\text { perso } \\
n\end{array}$ & $(\%)$ & $\begin{array}{l}\text { No. } \\
\text { of } \\
\text { per } \\
\text { son }\end{array}$ & $(\%)$ & $\begin{array}{l}\mathrm{N} \\
\text { o. } \\
\text { of } \\
\text { pe } \\
\text { rs } \\
\text { on }\end{array}$ & $(\%)$ & $\begin{array}{l}\mathrm{N} \\
\text { o. } \\
\text { of } \\
\text { pe } \\
\text { rs } \\
\text { on }\end{array}$ & $\begin{array}{l}(\% \\
)^{2}\end{array}$ \\
\hline & & 7 & 14 & 8 & 16 & 30 & 60 & 2 & 4 & 1 & 2 & 2 & 4 \\
\hline
\end{tabular}


Impact of Training Programs on Human Development: A study on Private Commercial Banks of Bangladesh

\begin{tabular}{|c|c|c|c|c|c|c|c|c|c|c|c|}
\hline S.I & Subject & Quarte & & \begin{tabular}{|l|} 
Every \\
Month
\end{tabular} & Six & Yearly & & $\begin{array}{l}\text { Every } \\
\text { Years }\end{array}$ & two & No speci & c schedule \\
\hline \multirow[t]{2}{*}{3} & \multirow{2}{*}{$\begin{array}{l}\text { Frequency } \\
\text { of training } \\
\text { (Graph-3) }\end{array}$} & $\begin{array}{l}\text { No. of } \\
\text { person }\end{array}$ & $(\%)$ & $\begin{array}{l}\text { No. of } \\
\text { person }\end{array}$ & $(\%)$ & $\begin{array}{l}\text { No. of } \\
\text { person }\end{array}$ & $(\%)$ & $\begin{array}{l}\text { No. of } \\
\text { person }\end{array}$ & $(\%)$ & $\begin{array}{l}\text { No. of } \\
\text { person }\end{array}$ & $(\%)$ \\
\hline & & 0 & 0 & 0 & 0 & 0 & 0 & 0 & 0 & 50 & 100 \\
\hline
\end{tabular}

\begin{tabular}{|c|c|c|c|c|c|c|c|c|c|c|c|c|c|}
\hline $\begin{array}{l}\text { S. } \\
\text { I }\end{array}$ & Subject & Lectur & & $\begin{array}{l}\text { Demonstr } \\
\mathrm{S}\end{array}$ & ation & Discuss & ions & $\begin{array}{l}\text { Presen } \\
\text { n }\end{array}$ & & Semina & & All & \\
\hline \multirow[t]{2}{*}{4} & \multirow{2}{*}{$\begin{array}{l}\text { Method } \\
\mathrm{s} \text { of } \\
\text { training } \\
\text { (Graph- } \\
\text { 4) }\end{array}$} & $\begin{array}{l}\text { No. of } \\
\text { perso } \\
n\end{array}$ & $\begin{array}{l}(\%) \\
(\%)\end{array}$ & $\begin{array}{l}\text { No. of } \\
\text { person }\end{array}$ & $(\%)$ & $\begin{array}{l}\text { No. of } \\
\text { perso } \\
n\end{array}$ & $\begin{array}{l}(\% \\
)\end{array}$ & $\begin{array}{l}\text { No. of } \\
\text { perso } \\
\text { n }\end{array}$ & (\%) & $\begin{array}{l}\text { No. of } \\
\text { perso } \\
n\end{array}$ & $\begin{array}{l}(\% \\
)\end{array}$ & $\begin{array}{l}\text { No. of } \\
\text { perso } \\
\text { n }\end{array}$ & (\% \\
\hline & & 5 & 10 & 0 & 0 & 9 & 18 & 3 & 6 & 6 & 12 & 27 & 54 \\
\hline
\end{tabular}

\begin{tabular}{|c|c|c|c|c|c|c|c|c|c|c|c|c|c|}
\hline S.I & Subject & \multicolumn{2}{|c|}{ Very Poor } & \multicolumn{2}{|l|}{ Poor } & \multicolumn{2}{|c|}{ Average } & \multicolumn{2}{|l|}{ Good } & \multicolumn{2}{|c|}{ Very good } & \multicolumn{2}{|c|}{ Excellent } \\
\hline \multirow[b]{2}{*}{5} & \multirow{2}{*}{$\begin{array}{l}\text { Quality } \\
\text { of } \\
\text { training } \\
\text { (Graph- } \\
\text { 5) }\end{array}$} & $\begin{array}{l}\text { No. of } \\
\text { person }\end{array}$ & $(\%)$ & $\begin{array}{l}\text { No. of } \\
\text { person }\end{array}$ & $(\%)$ & $\begin{array}{l}\text { No. of } \\
\text { person }\end{array}$ & $(\%)$ & $\begin{array}{l}\text { No. of } \\
\text { person }\end{array}$ & $(\%)$ & $\begin{array}{l}\text { No. of } \\
\text { person }\end{array}$ & $(\%)$ & $\begin{array}{l}\text { No. of } \\
\text { person }\end{array}$ & $(\%)$ \\
\hline & & 0 & 0 & 0 & 0 & 11 & 22 & 15 & 30 & 14 & 28 & 6 & 12 \\
\hline
\end{tabular}

\subsection{Test of Hypothesis}

For the hypothesis testing purpose, we assume that $95 \%$ of the employees are benefited from the training (i,e there is a positive relationship between training and human development).

We assume null hypothesis,

Null Hypothesis; $\mathrm{H}_{0}=$ Training Program has positive impact on human development.

Alternative Hypothesis; $\mathrm{H}_{1}=$ Training Program does not give positive impact on human development.

From the sample size 50, 50 people agree that training has positive impact on human development. So the value of proportion $\mathrm{p}=50 / 50=1$

And the value of $\pi=95 \%=.95$

So the value of $\mathrm{Z}$ is following-

$$
\begin{aligned}
\sigma & =\sqrt{\pi(1-\pi) / n} \\
& =\sqrt{.95(1-.95) / 50} \\
& =0.0308221 \\
\mathrm{Z}= & \frac{p-\pi}{\sigma} \\
= & \frac{1-.95}{.0308221} \\
= & 1.62
\end{aligned}
$$

The critical value of $Z$ is 1.96 at $5 \%$ significance level. Since, the computed value of $Z=1.62$ is less than the critical value of $Z=1.96$, therefore, the null hypothesis cannot be rejected. Hence, based on this sample data, there is a positive impact of training on human development.

\section{FOCUS GROUP DISCUSSION STATEMENT}

I was afraid of banking works when was selected for recruitment but on the job training enhances my confidence and increases my skill \& knowledge to this concern. I try to grab the opportunities to participate any training program arranged by the bank. It develops the employee productivity.(M. W. Muktadir,

Dhaka Bank Ltd.)

\section{FINDINGS OF THE STUDY}

The training program has positive effect on human development. From the study some crucial information are revealed, such as 
a) The training and development programs are designed on the grounds like general banking, credit, clearing, customer service, foreign exchange, legal documentation, anti money laundering etc.

b) The methods of training are lecture, demonstrations, discussion, presentation, seminar, and combination of these.

c) There is significant positive relationship between training and job performance (i.e. training develops the human of the organization)

d) The quality of training is very good in the opinion of employee and head of the branch.

e) There are lack of efficient and competent trainer and lack of accommodation facility in training center.

f) Training programs are huge time consuming that affect the performance of local branch.

\section{RECOMMENDATIONS}

The following recommendations may be helpful to decision makers in the private commercial banks about training and development program.

a) Training may be arranged on the virtual basis (using internet such as training with video conference).

b) Training should be conducted for the employees of all departments.

c) Customized training (need based training) should be arranged.

d) On joining training should be effective.

e) The topic of training should be selected on the contemporary issues.

f) The venue of training should be a branch or a region which reduce the time consuming of training.

g) The area of training should be enhanced (like behavioral training, time management training etc).

h) Repeated training programs should be arranged on complex banking terminology and issues.

\section{Conclusions}

Employees are major assets of any organization. The active role they play towards a company's success cannot be underestimated. As a result, equipping these unique assets through effective training becomes imperative in order to maximize the job performance. Human Resource Management is meant "to integrate all personal activities with each other and strategically with organizational objectives". The utilization of all other resources directly depends on efficient utilization of human resources. Every organization needs to have well-trained and experienced people to perform the activities that have to be done. As jobs have become more complex in the banking sector, the importance of employee training has increased. In a rapidly changing society, employee training is not only an activity that is desirable but also an activity that an organization must commit resources to, if it is to maintain a viable and knowledgeable workforce. Owing to the changing banking environment, HR department should care for appropriate response in equipping people who have to perform in the new environment. In this study, when effectiveness of training increases it directly has a positive influence on growth \& result of the banks. So training is really effective in all the banks that are taken for this study. In the banking sector, employee's behavior plays a vital role in improving the productivity of an organization. By incorporating personality development programs such as role play, group discussion and business games the superior and subordinate relationship can be strengthened. Banks should take necessary steps in such a way that employees should feel training is essential to enhance the productivity and customer satisfaction to meet the present business challenges in private commercial banks in Bangladesh.

\section{REFERENCES}

[1] Andrew Crosby. (2000). Training is Changing Call Centre Perception. Training Journal, Vol.13 No.4, pp. 18-21 Atul Gupta \& Susan T.Sadowski. (1998). End-User Training in the Service Industry. Managing Service Quality, Vol.8 No.3; pg 212

[2] Abdul-Hameed and Waheed, A. (2011), Employee Development and Its Affect on Employee Performance A Conceptual Framework International Journal of Business and Social Science Vol. 2 No. 13 [Special Issue - July 2011] 224

[3] Donald L. Kirkpatrick (1997), Evaluation, Training and Development Handbook

[4] Shishupal Singh Badhu and Karunesh Saxena (1999), Role of Training in Developing Human Resources 
Impact of Training Programs on Human Development: A study on Private Commercial Banks of Bangladesh

[5] Mehedi Hasan, Md. Hefzur Rahman, Md. Arifur Rahman, Employee Perception towards Effective Training Program: A Study on Some Selective Private Commercial Banks

[6] Rebeka Sultana Liza, Md.Abul Mohaimen, Tahmina Ferdous, Training Needs Analysis of Banking Sector in Bangladesh

[7] S.P. Gupta, M.P.Gupta, Business Statistics, page no-507

[8] Gary Dessler, Human Resource Management, page no-290-322

[9] Dr. Abdul Awal Khan, Dr. M. A. Taher, Human Resource Management and Industrial Relation , page -1

\section{AUTHOR'S BIOGRAPHY}

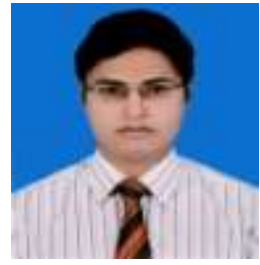

Md. Rafiul Islam, (BBA, MBA Major in Accounting \& Information Systems, Begum Rokeya University, Rangpur, Bangladesh)

Lecturer of Accounting, Department of Business Administration, Pundra University of Science \& Technology, Gokul, Bogra-5800, Bangladesh

APPENDIX- 1

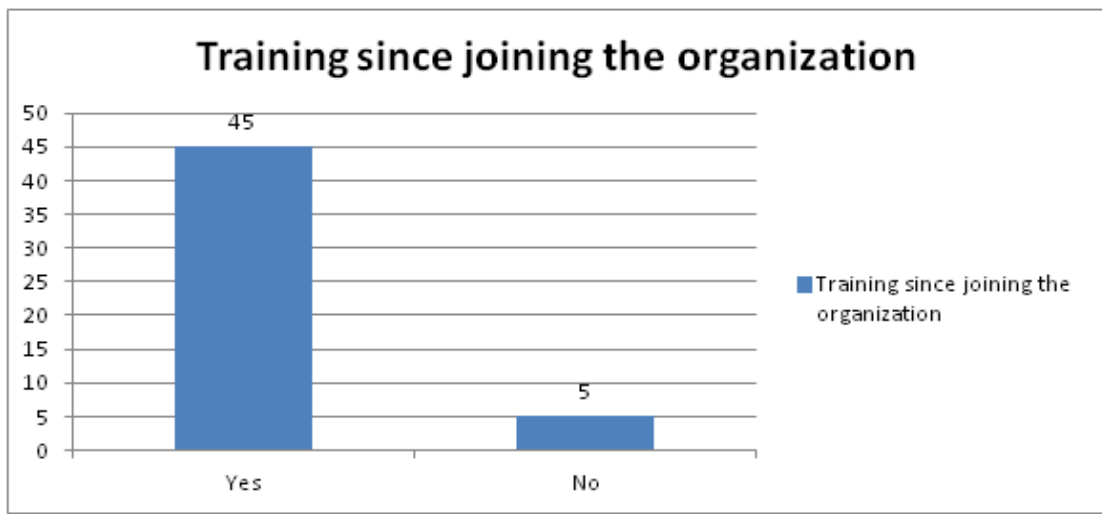

Graph1: Training since joining the organization

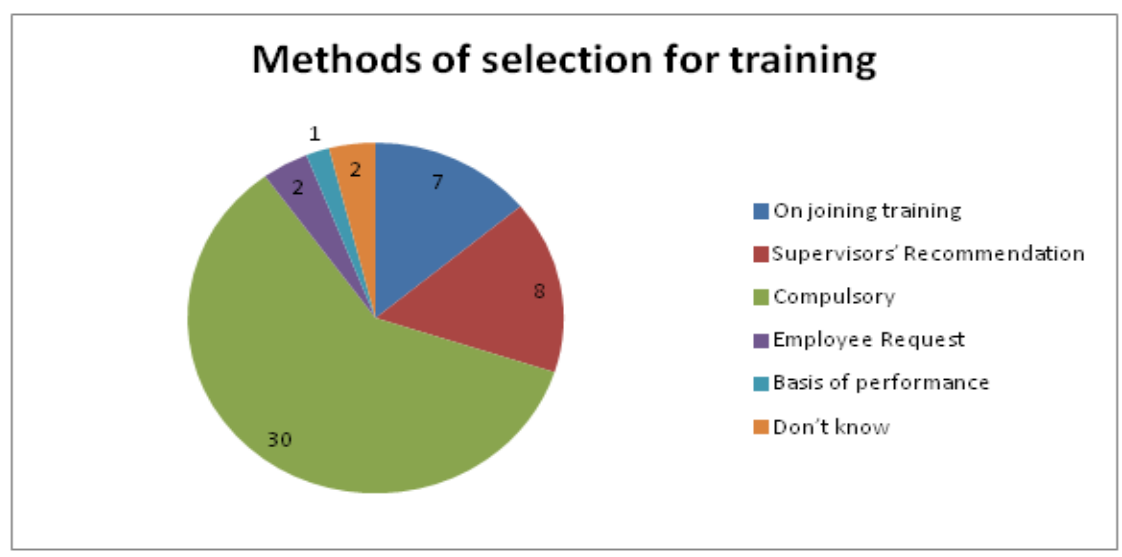

Graph2: Methods of selection for training

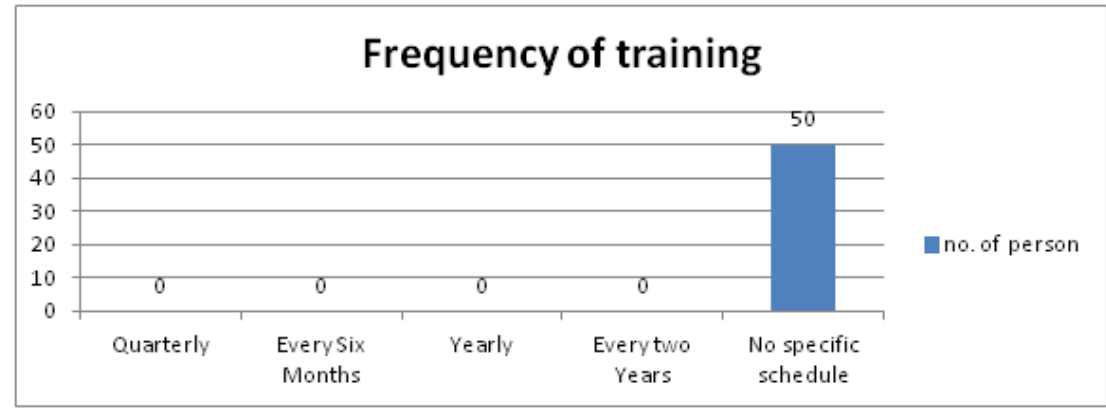

Graph3: Frequency of training 
Impact of Training Programs on Human Development: A study on Private Commercial Banks of Bangladesh

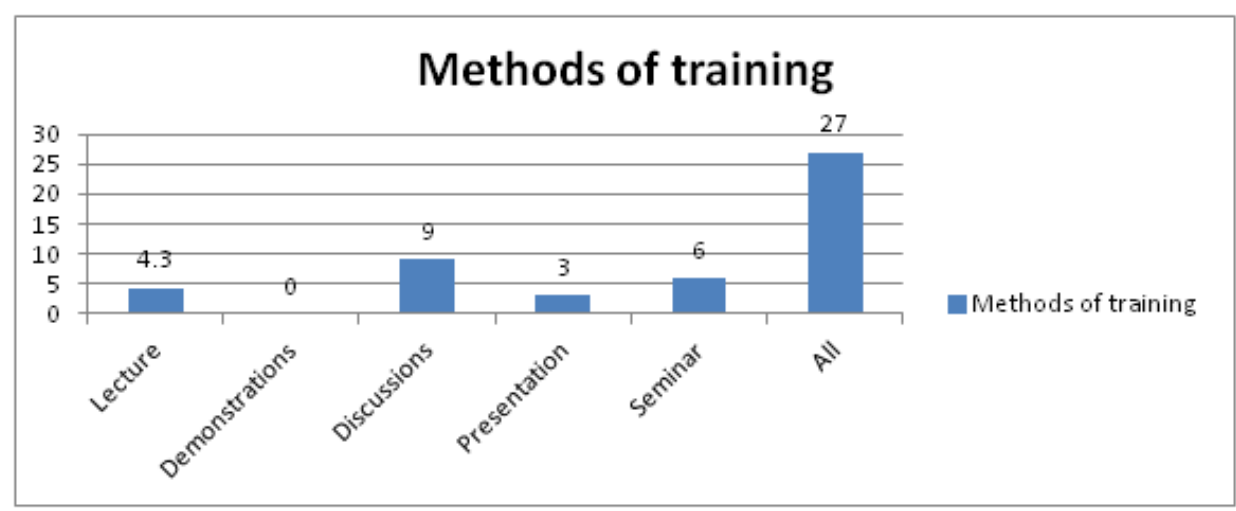

Graph4: Methods of training

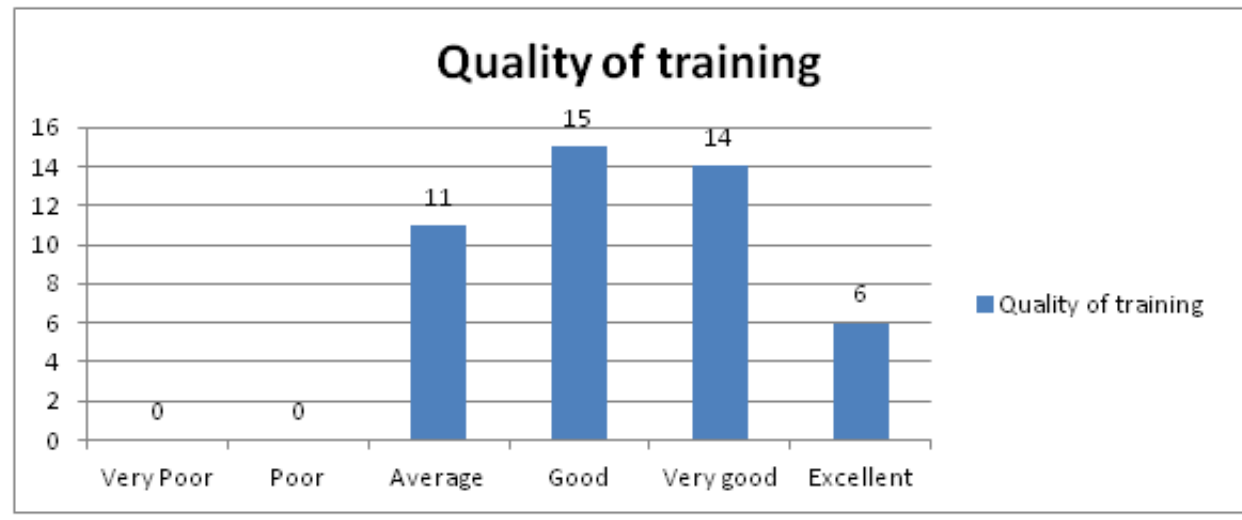

Graph5: Quality of training

Citation: Md. Rafiul, Islam*. "Impact of Training Programs on Human Development: A Study on Private Commercial Banks of Bangladesh." International Journal of Managerial Studies and Research (IJMSR), vol 5, no. 11, 2017, pp. 1-7. doi: http://dx.doi.org/10.20431/2349-0349.0511001.

Copyright: (c) 2017 Authors. This is an open-access article distributed under the terms of the Creative Commons Attribution License, which permits unrestricted use, distribution, and reproduction in any medium, provided the original author and source are credited. 